\title{
CAEP Position Statement - Management of devastating brain injuries in the emergency department: Enhancing neuroprognostication and maintaining the opportunity for organ and tissue donation - ERRATUM
}

Andrew Healey; Murdoch Leeies; Carmen Hrymak; Alecs Chochinov; Brian Grunau; Bojan Paunovic; Jeanne Teitelbaum; Lindsay C. Wilson; Sam D. Shemie

doi: $10.1017 /$ cem.2020.357

The original publication of Healey et al. (2020) contained an error in the title. The article is a CAEP Position Statement, not a CAEP Joint Position Statement.

The full correct title is "CAEP Position Statement Management of devastating brain injuries in the emergency department: Enhancing neuroprognostication and maintaining the opportunity for organ and tissue donation."
The publisher regrets this error. The original article has been updated.

\section{Reference}

Healey A et al. CAEP Position Statement - Management of devastating brain injuries in the emergency department: Enhancing neuroprognostication and maintaining the opportunity for organ and tissue donation. CFEM 2020;22(5):658-660. 